\title{
Effect of triaxial specimen size on engineering design and analysis
}

\author{
Tarek Omar ${ }^{*}$ and Abouzar Sadrekarimi
}

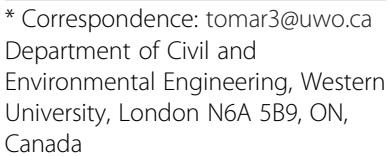

* Correspondence: tomar3@uwo.ca Department of Civil and Environmental Engineering, Western University, London N6A 5B9, ON Canada

\begin{abstract}
Background: Triaxial tests are often used to determine the behavior and strength characteristics of soils. Specimen size can have a significant impact on the measured shear strength. Accordingly, the selected parameters affect the related geotechnical engineering analysis and design.

Methods: We tested three different specimen sizes of loose Ottawa sand in triaxial compression tests. The measured shear strength and friction angle are used to explain some of the observed scale effects in engineering design and analysis. Critical state parameter and shear strength from the laboratory tests are employed to assess the static and seismic slope stability of an embankment dam, to calibrate a critical state soil constitutive model, to study the soil behavior under shallow foundations, and to evaluate liquefaction triggering and failure of retaining structures.

Results: We show that all of these analyses can be significantly affected by the choice of the specimen size used to determine shear strength parameters.

Conclusion: While using small size samples for determining shear strength parameters might result in un-conservative design, a large sample size is consequently a more accurate representation of soil strength conditions and field deformations.
\end{abstract}

Keywords: Scale effects; Sand; Shear strength; Critical state; Geotechnical engineering

\section{Introduction}

For cohesionless soils, the friction angle plays a decisive role in the shear strength and stability behavior. Accurate assessment of shear strength parameters for these soils is required for the analysis and design of soil structures (e.g., earth embankment dams, highway embankments, earth-retaining structures, foundations, slopes) involving cohesionless soil types. However, the size of the specimen used to determine soil strength parameters can have a significant impact on these parameters selected for analysis or design, making it difficult to extrapolate laboratory test results to real field situations. Different studies employ different specimen diameters $(D)$ and heights $(H)$ in triaxial compression tests. The behavior of a particular soil from different studies are often compared without due attention to the differences in specimen size and its effect on soil shear behavior. Therefore, this phenomenon is either totally neglected in extending laboratory test results on a small specimens to engineering design and analysis, or laboratory test results are simply distrusted and the design or analysis is based on empirical interpretations of in-situ field tests (e.g., SPT or CPT) which could also involve

\section{Springer}

(c) 2015 Omar and Sadrekarimi. This is an Open Access article distributed under the terms of the Creative Commons Attribution License (http://creativecommons.org/licenses/by/4.0), which permits unrestricted use, distribution, and reproduction in any medium, provided the original work is properly credited. 
a wide range of uncertainties. In this study, a comprehensive experimental program is conducted to investigate the sample size effect associated with shear banding and specimen boundary conditions on the consolidation, drained and undrained shear behavior of very loose Ottawa sand specimens. The measured sand shear strength and friction angle in triaxial compression tests on three different specimen sizes are used to explain some of the scale effects observed in engineering design and analysis.

\section{Experimental program and results}

Static triaxial compression tests (24 number drained and undrained tests) were performed on loose sand specimens with different cylinder sizes sealed in a water-tight rubber membrane and confined in a water-filled acrylic cell. The details of the monotonic triaxial compression shear tests are briefly described below.

\section{Properties of the tested sand}

The experiments were conducted on a clean, uniformly-graded Ottawa sand - classified as a SP according to the Unified Soil Classification System (ASTM Standard D2487 2011) with round to sub-round particle shapes. Sieve analysis was performed on the sand, and average mean particle size $\left(D_{50}\right)$, coefficient of uniformity $\left(C_{U}\right)$, and coefficient of curvature $\left(\mathrm{C}_{\mathrm{C}}\right)$ of $0.22 \mathrm{~mm}, 1.71$, and 1.07 were determined, respectively. Specific gravity of the sand particles $\left(G_{S}\right)$, and maximum and minimum void ratios of respectively $2.65,0.821$, and 0.487 were measured following the ASTM standard procedures (ASTM Standard D854 2014; ASTM Standard D4253 (2006; ASTM Standard D4254 2006).

\section{Specimen preparation}

Non-uniform deformations in triaxial testing often result from the physical boundary restraints as a result of friction between the soil specimen and the end platens (Bishop and Green 1965; Lee 1978). This end restraint could affect the pore pressure or volume change measurements and lead to incorrect shear strength parameters. In order to reduce specimen non-uniform deformation and strain localization at large strains (Rowe and Barden 1964; Bishop and Green 1965; Colliat-Dangus et al. 1988), cylindrical specimens of 38,50 , and $70 \mathrm{~mm}$ diameters were prepared with equal height and diameter $(H / D=1)$ and the end restraints were nearly eliminated by employing enlarged and lubricated end platens. As illustrated in Fig. 1, two latex membranes discs of $0.3 \mathrm{~mm}$ thickness were trimmed to the same specimen diameter with a central hole cut to the diameter of the porous stone to allow drainage. The two discs were smeared with a very thin layer of silicon grease and placed over the specimen caps. An additional layer of high vacuum silicon grease was smeared on the rubber discs in order to provide a smooth and frictionless sliding on the end platens. The smear of silicon grease between the latex sheets allowed nearly frictionless sliding of the specimen on the loading platens and minimized end restrains. Specially designed split moulds were constructed to accommodate the enlarged platens during specimen preparation.

As this study was focused on investigating the effects of specimen size on the behavior of loose sands, static liquefaction, and critical state testing, all specimens were prepared at an initial void ratio $\left(\mathrm{e}_{\mathrm{i}}\right)$ of 0.821 , corresponding to an initial relative density $\left(\mathrm{D}_{\mathrm{ri}}\right)$ of $0 \%$. Moist tamping was used for preparing loose specimens which would exhibit entirely strainsoftening and liquefaction (in undrained shear) or contractive (in drained shear) behavior 


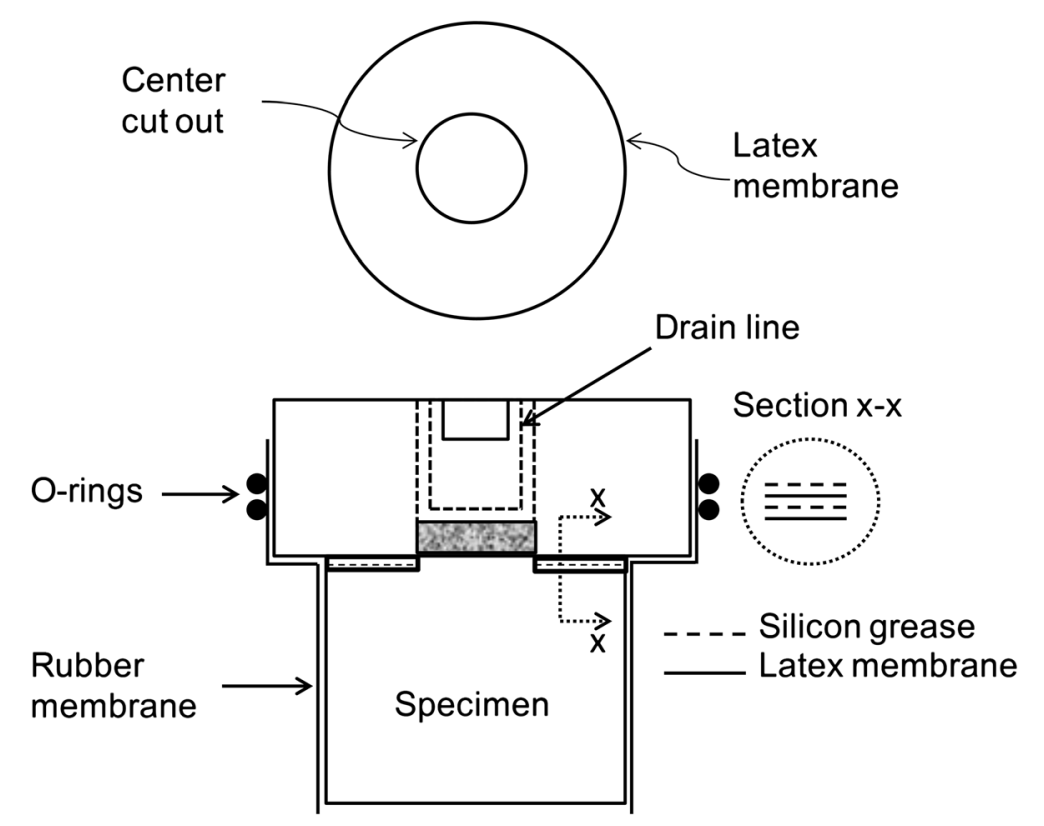

Fig. 1 Procedure of developing lubricated end platens (stainless steel)

(Ishihara 1993; Sadrekarimi and Olson 2011). In order to minimize density variations and void ratio non-uniformities within a specimen, the undercompaction technique introduced by Ladd (1978) was employed to produce a relatively uniform void ratio throughout the specimen height. This method involves the compaction of each layer slightly looser than the target global density, with the bottom layer compacted the least and the top layer compacted the most, so that the final density of each layer, even with the effects of compaction of the successive overlaying layers, would be equal to the target global density. The moist unit weight and void ratio of each layer were calculated based on the target overall $\mathrm{D}_{\mathrm{ri}}=0 \%$ with a maximum undercompaction ratio of $10 \%$ for the bottom layer. The percent undercompaction used for calculating the moist weight of each layer was linearly decreased from $10 \%$ at the bottom to $0 \%$ at the top layer. Specimen uniformity was assessed by preparing a similar specimen with several small containers embedded within the sand throughout the specimen height. After specimen preparation, the specimen was gently excavated and these small containers were extracted. The weight and volume of sand in each container were then carefully measured in order to determine sand void ratio. We observed that the void ratio of these samples deviated by less than $\pm 0.6 \%( \pm 0.005)$ from the average void ratio of the specimen. This is consistent with the void ratio variations of undercompacted moisttamped specimens found by Sasitharan (1994).

\section{Triaxial testing procedure}

Monotonic triaxial compression tests were performed in this study using an automated stress path triaxial testing system consists of loading frame, two electromechanical pressure pumps, and a data acquisition and control system. The system also includes an external load cell, a deformation sensor, and three fluid pressure sensors. Axial deformation of the sample during shear is measured externally by a linear variable displacement transducer (LVDT). Specimen saturation started by percolating carbon dioxide $\left(\mathrm{CO}_{2}\right)$ through the specimen followed by flushing with deaired water. As 
complete specimen saturation was necessary for accurate volume change and pore pressure measurements, the saturation procedure was proceeding with a backpressure saturation phase as recommended by Black and Lee (1973). A back pressure of 200 $\mathrm{kPa}$ was applied to the specimens' pore water in order to drive any remaining air into solution. Saturation was verified by ensuring that a Skempton's pore water pressure parameter, B of at least 0.98 was achieved in all specimens. Isotropic consolidation commenced subsequent to the completion of specimen saturation by increasing of the effective confining pressure $\left(\mathrm{p}_{\mathrm{c}}^{\prime}\right)$. The volume of water driven out of the sample was measured from the change in the pore pump volume before and after consolidation and hence the post-consolidation void ratio $\left(e_{c}\right)$ was readily obtained. Specimens were sheared following isotropic consolidation up to an axial strain of $30 \%$ at an axial strain rate of $5 \% / \mathrm{h}$ (corresponding to $0.032,0.042$, and $0.058 \mathrm{~mm} / \mathrm{min}$ for the $38 \mathrm{~mm}$, $50 \mathrm{~mm}$, and $70 \mathrm{~mm}$ specimens, respectively) to ensure full pore pressure equalization during undrained shearing and complete excess pore pressure dissipation during drained shear. Specimen void ratio was calculated from the volume change measurements during the drained shear tests while a constant specimen volume was maintained in the undrained shear tests. Table 1 summarizes the specifications of the triaxial tests of this study.

Table 1 Specifications of the triaxial compression tests

\begin{tabular}{|c|c|c|c|c|}
\hline Test No. ${ }^{a}$ & $\begin{array}{l}\mathrm{D}_{\mathrm{s}} \\
(\mathrm{mm})\end{array}$ & $\begin{array}{l}\mathrm{p}_{\mathrm{c}}^{\prime} \\
(\mathrm{kPa})\end{array}$ & $e_{c}$ & $\begin{array}{l}D_{r c} \\
(\%)\end{array}$ \\
\hline MT-1D & 70 & 500 & 0.771 & 15 \\
\hline MT-2D & & 300 & 0.779 & 13 \\
\hline MT-3D & & 200 & 0.785 & 11 \\
\hline MT-4D & & 100 & 0.797 & 7 \\
\hline MT-5UD & & 500 & 0.775 & 14 \\
\hline MT-6UD & & 300 & 0.782 & 12 \\
\hline MT-7UD & & 200 & 0.791 & 9 \\
\hline MT-8UD & & 100 & 0.797 & 7 \\
\hline MT-9D & 50 & 500 & 0.761 & 18 \\
\hline MT-10D & & 300 & 0.769 & 16 \\
\hline MT-11D & & 200 & 0.773 & 14 \\
\hline MT-12D & & 100 & 0.786 & 10 \\
\hline MT-13UD & & 500 & 0.769 & 16 \\
\hline MT-14UD & & 300 & 0.775 & 14 \\
\hline MT-15UD & & 200 & 0.785 & 11 \\
\hline MT-16UD & & 100 & 0.795 & 8 \\
\hline MT-17D & 38 & 500 & 0.76 & 18 \\
\hline MT-18D & & 300 & 0.766 & 16 \\
\hline MT-19D & & 200 & 0.775 & 14 \\
\hline MT-20D & & 100 & 0.786 & 10 \\
\hline MT-21UD & & 500 & 0.766 & 16 \\
\hline MT-22UD & & 300 & 0.773 & 14 \\
\hline MT-23UD & & 200 & 0.784 & 11 \\
\hline MT-24UD & & 100 & 0.794 & 8 \\
\hline
\end{tabular}

${ }^{a} \mathrm{D}$ and $\mathrm{UD}$ in test labels indicate drained and undrained shearing, respectively 


\section{Corrections for triaxial compression test results}

Triaxial shear tests involve several sources of errors that could significantly affect test results if not corrected. Corrections were made in this study to account for: 1) volume change due to backpressure saturation (ASTM Standard D4767 2011), 2) membrane penetration (Baldi and Nova 1984), 3) axial deformation due to bedding errors (Sarsby et al. 1980; Russell and Khalili 2004) during both isotropic compression and shearing, 4) membrane resistance (ASTM Standard D7181 2011), and 5) change of specimen cross-sectional area during shear (Garga and Zhang 1997). As explained earlier, slenderness ratio of unity and enlarged and lubricated end platens were employed in the experiments of this study to allow free radial expansion of the specimen and minimize bulging deformation during shear. Fig. 2 demonstrates the effectiveness of lubricated ends and the adopted slenderness ratio in producing a uniform specimen deformation pattern at an axial strain of $30 \%$.

Corrections for membrane resistance, area correction and enlarged/lubricated platens resulted in cumulative reductions of about $11 \%$ and $3.5^{\circ}$ of undrained shear strength and critical state friction angle, while correction for specimen volume and cross sectional area change during saturation increased these strength parameters by about $1.5 \%$ and $0.9^{\circ}$, respectively. Membrane penetration resulted only in an average of $0.36 \%$ decrease in void ratio during isotropic consolidation and undrained shear tests as the fine gradation of the tested sand limited the amount of membrane penetration into the surface irregularities of the specimen. The bedding errors due to the application of lubricated ends led to a maximum increase in volumetric strain of $1.7 \%$ during isotropic compression and an additional $0.38 \mathrm{~mm}$ or $2.5 \%$ increase in the measured axial strain during shearing. The corrected results are presented to compare the responses for different specimen sizes during isotropic compression and shearing in the following paragraphs.

\section{Isotropic compression response}

Figure 3 presents the isotropic compression lines following the consolidation phase for the different specimen sizes tested in this study where the $38 \mathrm{~mm}$ specimens display the most compressive response during isotropic compression (i.e., steepest compression line) followed by the 50 and $70 \mathrm{~mm}$ specimen sizes. In other words, the $70 \mathrm{~mm}$

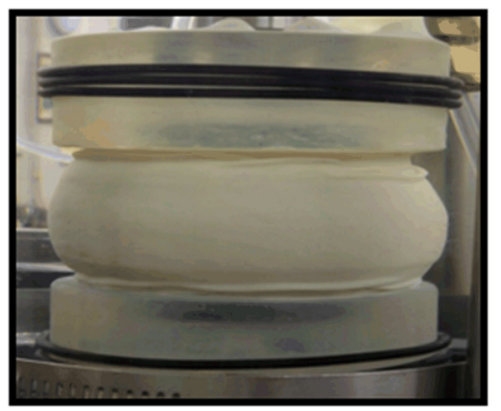

(a)

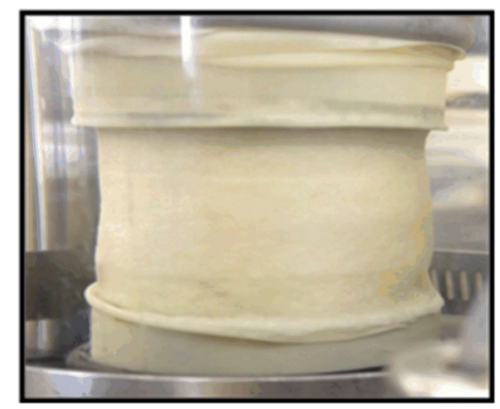

(b)

Fig. 2 Deformation pattern of a loose sand specimen (a) without, and (b) with enlarged and lubricated end platens in triaxial compression tests at $30 \%$ axial strain 


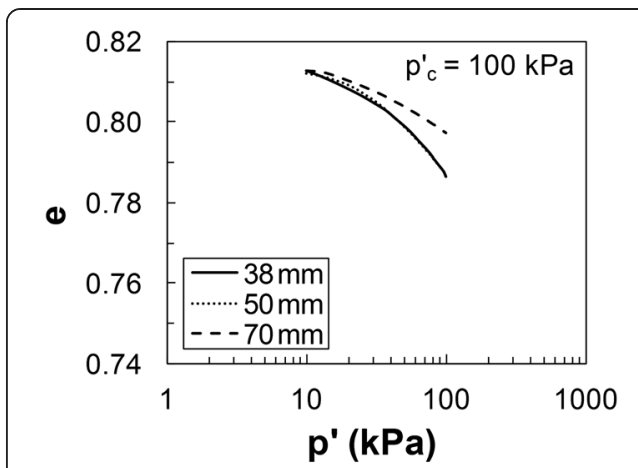

(a)

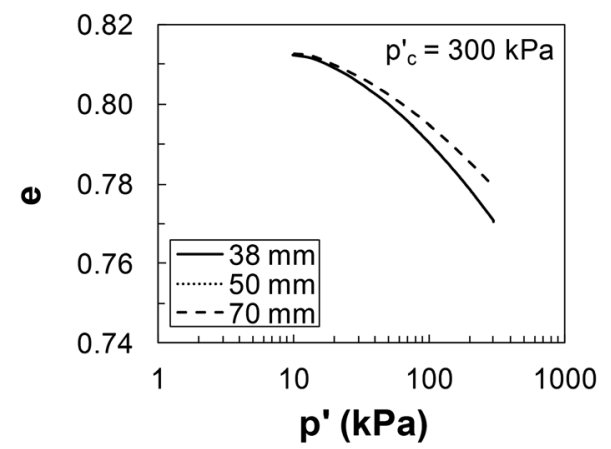

(c)

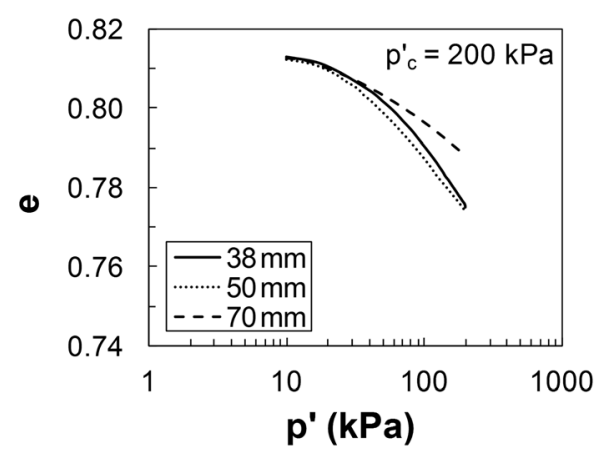

(b)

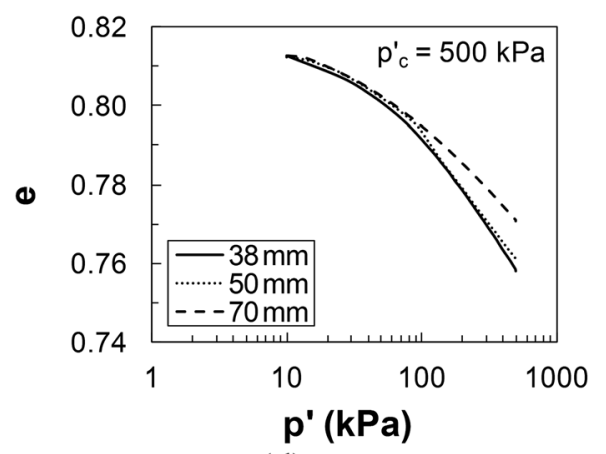

(d)

Fig. 3 Effect of specimen size on the isotropic compression behavior of loose Ottawa sand at (a) $p_{c}^{\prime}=100 \mathrm{kPa}$, (b) $\mathrm{p}_{c}^{\prime}=200 \mathrm{kPa}$, (c) $\mathrm{p}_{c}^{\prime}=300 \mathrm{kPa}$, and (d) $\mathrm{p}_{c}^{\prime}=500 \mathrm{kPa}$

specimens experienced less volumetric strains than the 38 and $50 \mathrm{~mm}$ specimens at the same $\mathrm{p}_{\mathrm{c}}$ in all tests. This indicates that larger sand specimens exhibit markedly stiffer isotropic compression behavior and smaller compressibility during isotropic compression. The slight differences in $\mathrm{e}_{\mathrm{c}}$ is however within the void ratio variations of most triaxial tests (Jefferies et al. 1990).

\section{Undrained shear behavior}

Figure 4 compares the undrained deviator stress versus axial strain behavior from the triaxial compression tests on different specimen sizes. Although, all of the specimens exhibit strain-softening behaviors, the deviator stress mobilized throughout the tests is consistently larger in the smaller specimens and the axial strain $\left(\varepsilon_{\mathrm{a}}\right)$ corresponding to the peak deviator stress increases with decreasing specimen size. Although the lower deviator stresses mobilized in the $70 \mathrm{~mm}$ specimens could be partly due to their slightly looser void ratios, the 50 and $38 \mathrm{~mm}$ specimens were sheared from the same $\mathrm{e}_{\mathrm{c}}$ and still exhibit specimen size effects. On the other hand, Fig. 5 shows the excess pore water pressures $(\Delta \mathrm{u})$ developed during undrained shear in the different specimen sizes consolidated to the same $\mathrm{p}_{\mathrm{c}}^{\prime}$. An equal $\Delta \mathrm{u}$ are developed after an axial strain of $10 \%$ where a critical state is reached. This implies that although the contraction tendency of the sand fabric was the same for all specimen sizes, the mobilized strength, deviator stress, and the strain-softening behaviors include an inherent specimen size dependency at similar $\varepsilon_{\mathrm{a}}$. 


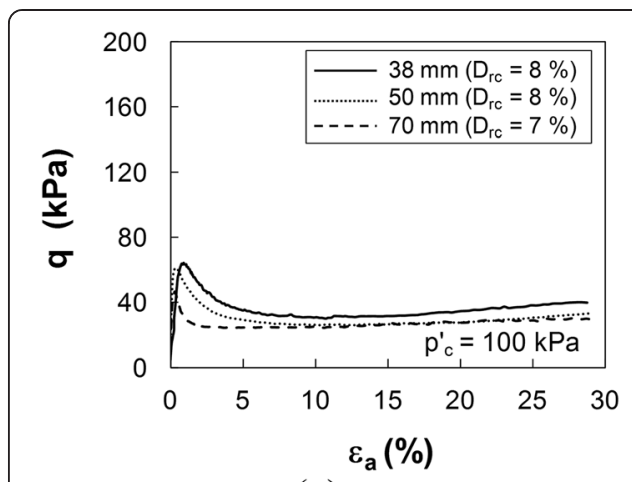

(a)

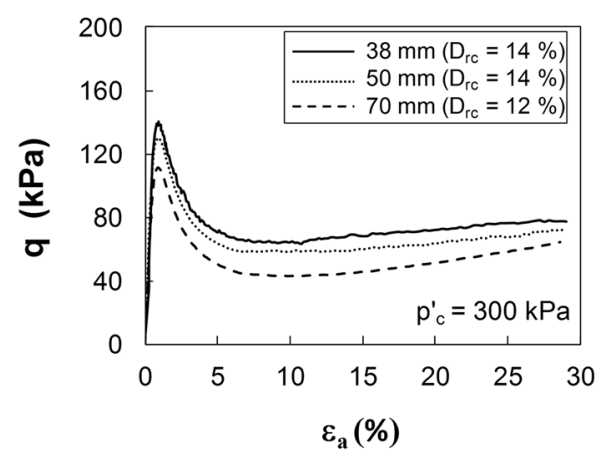

(c)

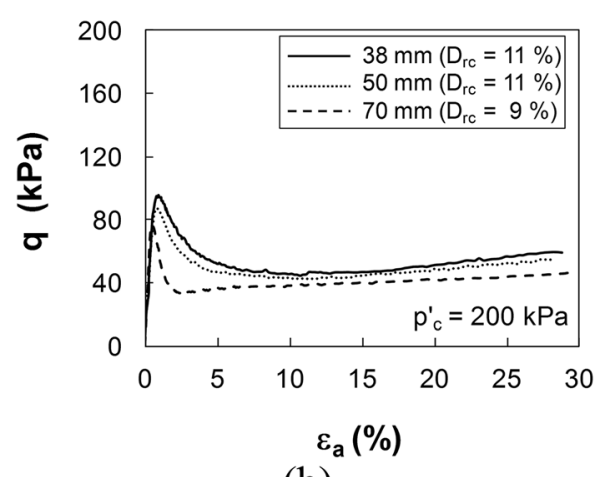

(b)

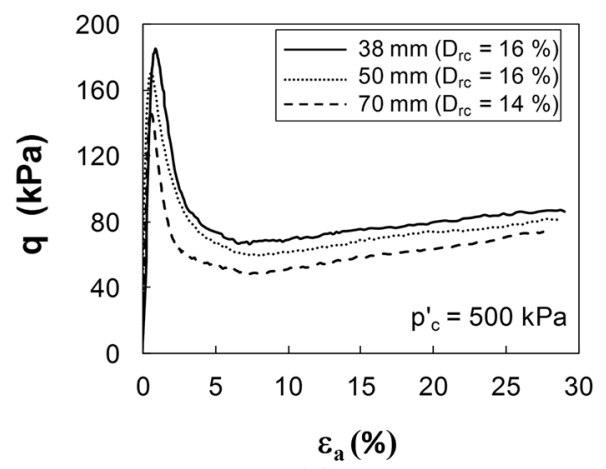

(d)

Fig. 4 Undrained stress - strain behaviors of different specimen sizes in triaxial compression shear tests at (a) $p_{c}^{\prime}=100 \mathrm{kPa},(\mathbf{b}) \mathrm{p}_{\mathrm{C}}^{\prime}=200 \mathrm{kPa},(\mathbf{c}) \mathrm{p}_{\mathrm{C}}^{\prime}=300 \mathrm{kPa}$, and (d) $\mathrm{p}_{\mathrm{C}}^{\prime}=500 \mathrm{kPa}$

\section{Drained shear behavior}

Figure 6 compares the drained shearing behaviors of different specimen sizes where larger deviator stresses are mobilized in the smaller specimens. Similar to the undrained shear tests, although the lower deviator stress of the $70 \mathrm{~mm}$ specimens could be partly associated with their slightly looser $\mathrm{e}_{\mathrm{c}}$, the 50 and $38 \mathrm{~mm}$ diameter specimens were sheared from the same $e_{c}$ and exhibit specimen size effects. Fig. 7 compares the rate of volumetric contraction $\left(C=\partial \varepsilon_{\mathrm{v}} / \partial \varepsilon_{\mathrm{a}}\right)$ obtained from specimens of different sizes during the drained shear tests. All specimens show volumetric contraction with a steady reduction in the rate of volume change with $\varepsilon_{\mathrm{a}}$ (i.e., dilatancy) followed by an almost flat plateau of constant-volume behavior $\left(\varepsilon_{\mathrm{v}}=0\right)$ at the critical state with some specimens exhibiting slight volumetric dilation at large strains. Hypothetically, the same sand at the same $\mathrm{p}_{\mathrm{c}}^{\prime}$ and $\mathrm{e}_{\mathrm{c}}$ should exhibit similar volumetric strains during shear. However, these plots demonstrate that $\varepsilon_{\mathrm{v}}$ and $C$ increase with decreasing specimen size, with the peak volumetric contraction occurring at an early $\varepsilon_{\mathrm{a}}$ of about $1 \%$.

\section{Effective stress paths}

The effective stress paths obtained from the testing of different specimen sizes are compared in Figs. 8 and 9 for drained and undrained shearing conditions, respectively. The undrained effective stress paths of all specimen sizes reach an instability line (IL) which defines the lower bound of all the possible unstable conditions (Lade 1992). The undrained stress paths then move into the region of instability, and approach a critical 


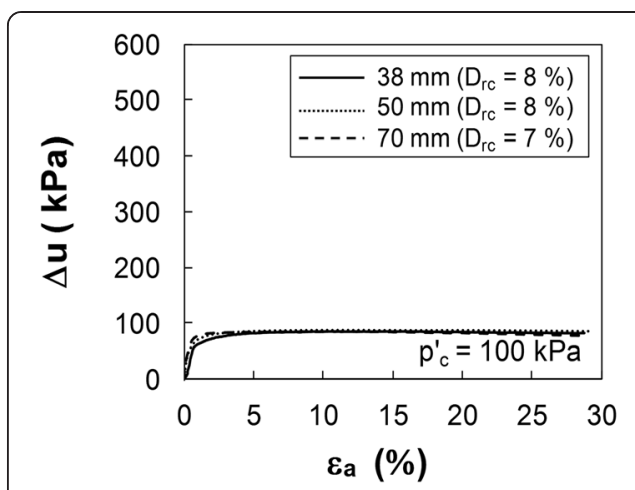

(a)

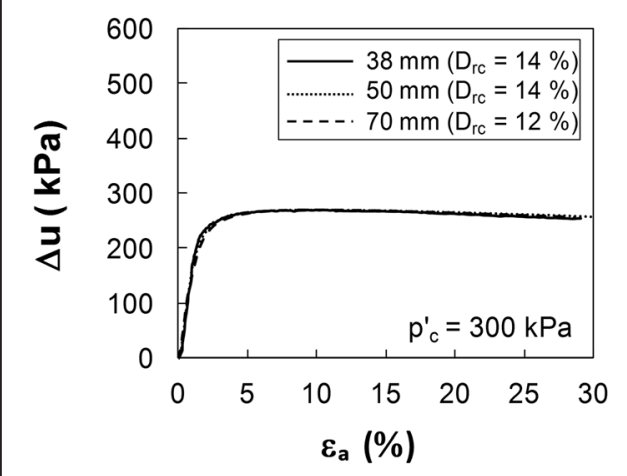

(c)

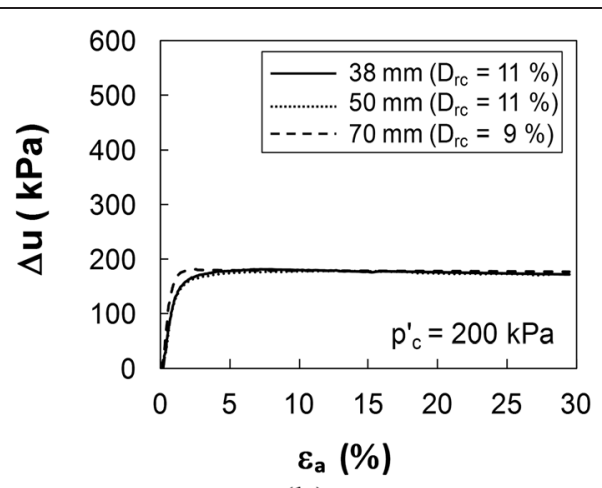

(b)

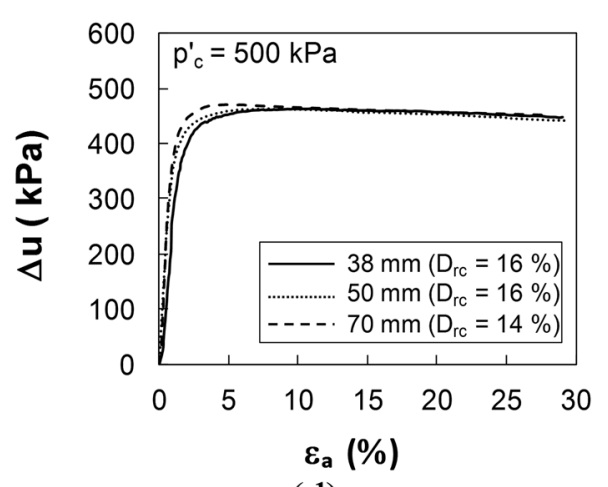

(d)

Fig. 5 Excess pore water pressure developed during undrained triaxial compression tests on different specimen sizes at (a) $p_{c}^{\prime}=100 \mathrm{kPa},(\mathbf{b}) p_{c}^{\prime}=200 \mathrm{kPa},(\mathbf{c}) p_{c}^{\prime}=300 \mathrm{kPa}$, and (d) $p_{c}^{\prime}=500 \mathrm{kPa}$

stress ratio (CSR), corresponding to the CSL of each specimen size. The drained stress paths also reach the CSR, but without exhibiting unstable behavior. Unique CSR are obtained from both the undrained and drained stress paths for each specimen size, which become steeper with decreasing specimen size.

\section{Effective friction angle}

Granular soils mobilize shear resistance through their internal friction angle, and therefore friction angle is considered as the most important mechanical property to analyze granular soils' response to loading. The friction angle $\left(\phi_{\text {mob }}^{\prime}\right)$ mobilized in a triaxial compression shear test is calculated from the effective stress ratio $\left(M=q / p^{\prime}\right)$ using the following equation

$$
\phi_{\mathrm{mob}}^{\prime}=\sin ^{-1}\left(\frac{3 M}{6+M}\right)
$$

The mobilized friction angle corresponding to the slope of the instability line (in Fig. 9) is referred to as the yield friction angle ( $\left.\phi_{\text {yield }}^{\prime}\right)$ which is obtained from the undrained shear tests. Table 2 summarizes the measured $\phi_{\text {yield }}^{\prime}$ and $\phi_{\mathrm{cs}}^{\prime}$ for each specimen subject to different confining stresses and drainage conditions. The effect of specimen size on $\phi_{\text {yield }}^{\prime}$ and $\phi_{\mathrm{cs}}^{\prime}$ is summarized in Fig. 10 which shows that the size of a specimen can have a profound effect on the $\phi_{\text {yield }}^{\prime}$ and $\phi_{\mathrm{cs}}^{\prime}$ measured from triaxial compression shear tests. 


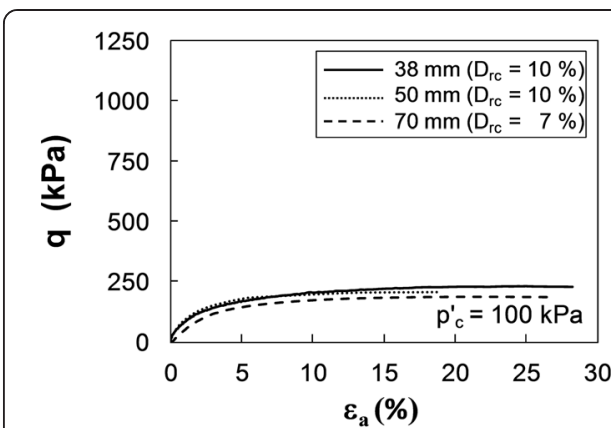

(a)

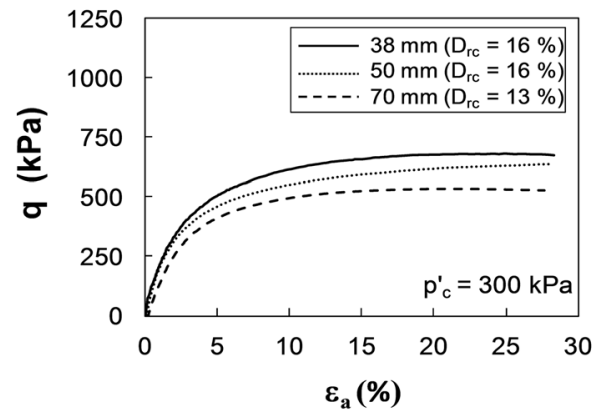

(c)

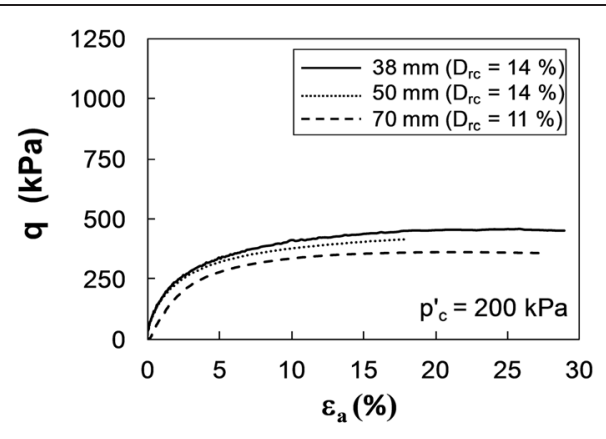

(b)

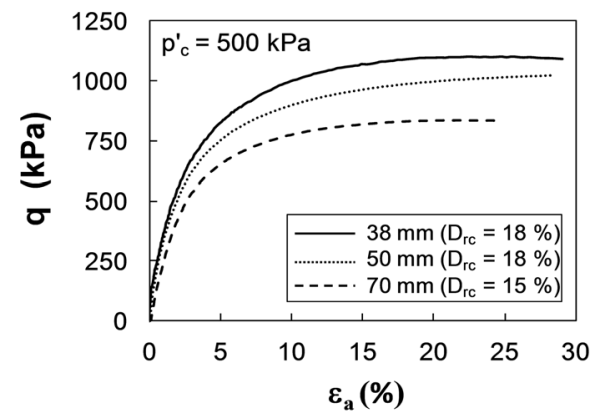

(d)

Fig. 6 Drained stress - strain behaviors of different specimen sizes in triaxial compression shear tests at (a) $\mathrm{p}_{\mathrm{c}}^{\prime}=100 \mathrm{kPa},(\mathbf{b}) \mathrm{p}_{\mathrm{c}}^{\prime}=200 \mathrm{kPa},(\mathbf{c}) \mathrm{p}_{\mathrm{c}}^{\prime}=300 \mathrm{kPa}$, and (d) $\mathrm{p}_{\mathrm{c}}^{\prime}=500 \mathrm{kPa}$

\section{Critical state parameters}

The projection of the CSL in the e - $\log \left(\mathrm{p}_{\mathrm{c}}^{\prime}\right)$ plane from the undrained and drained triaxial compression tests on different specimen sizes is illustrated in Fig. 11. According to this figure, although unique CSLs are established from drained and undrained shear tests for each specimen size, the CSLs become steeper and largely shift to denser void ratios with decreasing specimens' diameter from $70 \mathrm{~mm}$ to $38 \mathrm{~mm}$, reflecting the less compressible response of the larger specimens. The significant change of the CSL and the critical state parameters $\left(\lambda_{\mathrm{cs}}, \Gamma_{\mathrm{cs}}\right.$, and $\left.\phi_{\mathrm{cs}}^{\prime}\right)$ would have large effects in estimating soil state parameter.

\section{Undrained shear strength}

Based on the Mohr-Coulomb failure theory, the undrained shear strength $\left(s_{u}\right)$ is obtained from the deviator stress (q) as below:

$$
s_{u}=\frac{q}{2} \cos \left(\phi_{m o b}^{\prime}\right)
$$

Accordingly, as presented in the stress-strain plots of Fig. 4, a peak undrained shear strength, $\mathrm{s}_{\mathrm{u}}$ (yield) is attained at $\varepsilon_{\mathrm{a}} \approx 1 \%$. This is followed by significant drop of the undrained shear resistance as a result of rapid increase in the excess pore pressure at constant volume. Strain-softening continues until a more-or-less constant undrained strength is mobilized at the critical state, $s_{u}$ (cs). Fig. 12 describes the increasing of $s_{u}$ (yield) and $s_{u}$ (cs) with increasing $p_{c}^{\prime}$ for each specimen size. According to this figure, $s_{u}$ (yield) and $s_{u}$ (cs) increase not only with increasing $\mathrm{p}_{c}^{\prime}$ and $D_{r c}$, but 


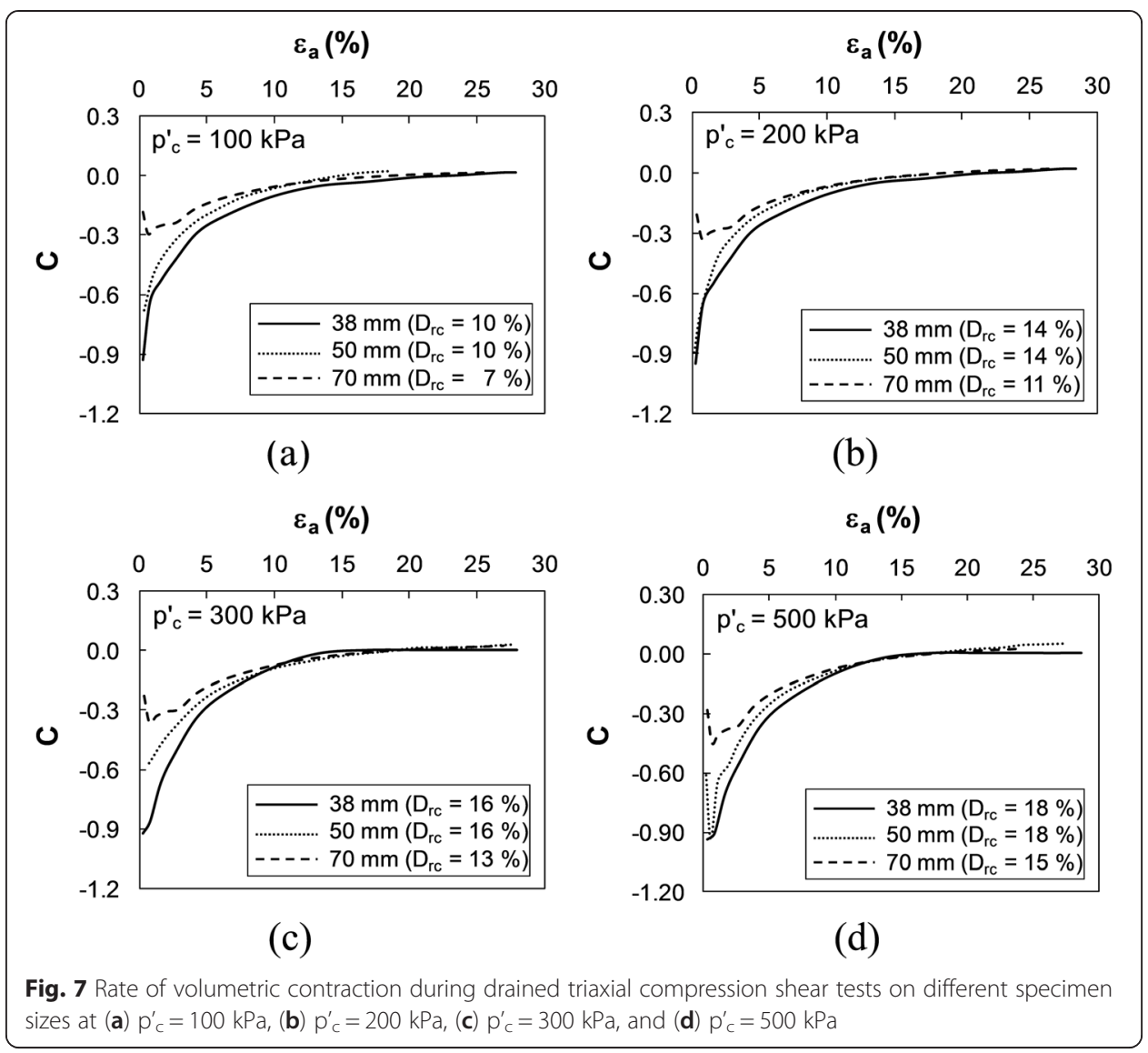

also with decreasing specimen size. Again the lower undrained shear strengths of the $70 \mathrm{~mm}$ specimens partly results from their slightly looser $\mathrm{D}_{\mathrm{rc}}$ besides the effect of specimen size, whereas the effect of specimen size on the undrained strengths of the $50 \mathrm{~mm}$ and $38 \mathrm{~mm}$ specimens is undeniable as they were sheared from the same consolidation conditions.

\section{Influence of sample size in engineering practice}

The higher compressibility of smaller specimens during isotropic compression and drained shearing could be due to the larger volumetric fraction of the sand particles near the specimen's sides. Additional compression of the latex and grease layers (at the top and bottom caps) associated with possible inaccuracies of the employed bedding error correction method (Sarsby et al. 1980; Russell and Khalili 2004) may have also contributed to the larger compressibility of the smaller specimens. Although no shear bands were observed at the end of the tests on the exterior surface of the specimens, as suggested by earlier studies (Tatsuoka et al. 1991; Desrues et al. 1996; Finno et al. 1996; Jang and Frost 2000; Alshibli and Sture 2000) it is quite possible that a complex and diffuse mode of failure and shear localization (involving multiple shear bands) developed in the specimens. The lower deviator stresses of the larger specimens (in Figs. 4 and 6) could be associated with the more intense strain-softening resulting from shearing along longer and larger number of shear bands formed in larger specimens and the 


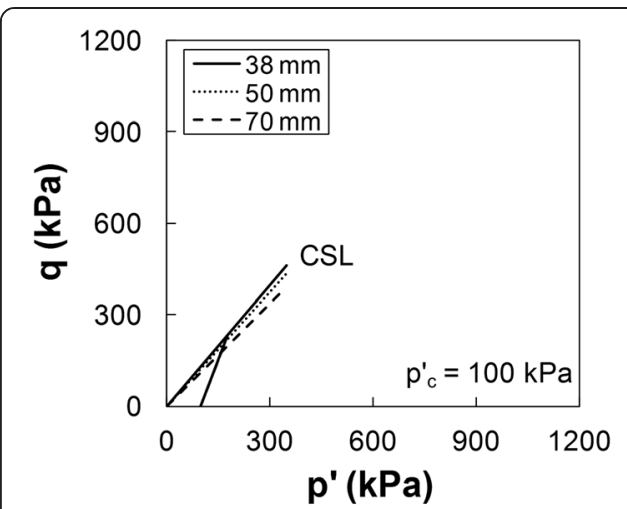

(a)

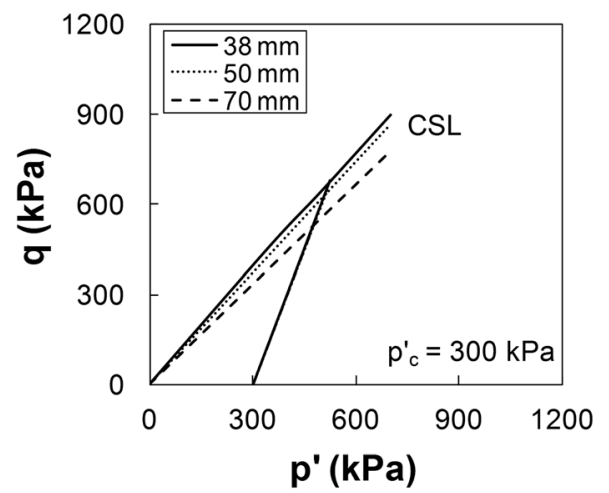

(c)

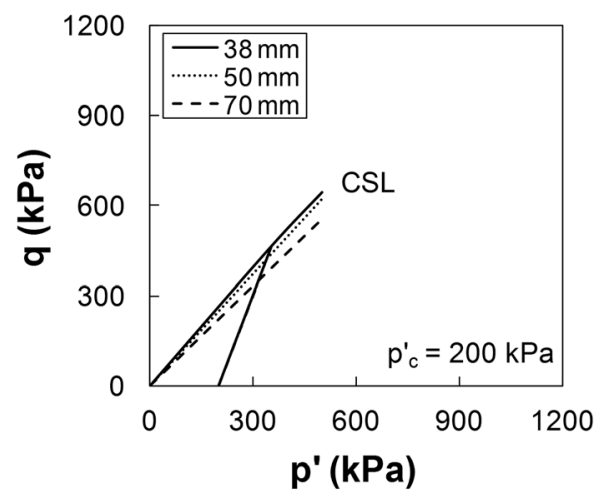

(b)

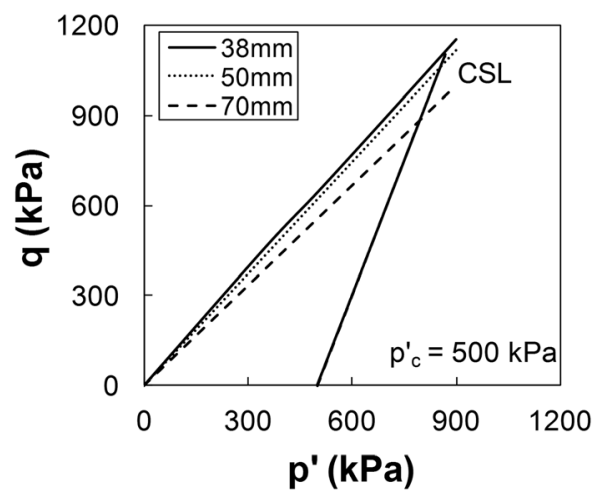

(d)

Fig. 8 Effect of specimen size on drained effective stress paths of Ottawa sand at (a) $p_{c}^{\prime}=100 \mathrm{kPa}$, (b) $\mathrm{p}_{\mathrm{c}}^{\prime}=200 \mathrm{kPa},(\mathbf{c}) \mathrm{p}_{\mathrm{C}}^{\prime}=300 \mathrm{kPa}$, and (d) $\mathrm{p}_{\mathrm{C}}^{\prime}=500 \mathrm{kPa}$

differences in the available space or freedom for particle rearrangement in the specimens of different sizes. Similar mechanisms leading to specimen size effects have been also observed in compression tests (Andrews et al. 2001; Bastawros et al. 2000; Chen and Fleck 2002; Hakamada et al. 2007; Jeon and Asahina 2005; Park and Nutt 2001) and in numerical modeling studies (Chen and Fleck 2002; Onck et al. 2001; Tekoglu et al. 2011) of foam materials. While results from the current study are focused on a narrow set of very loose $\mathrm{D}_{\mathrm{rc}}(7-18 \%)$, specimen size effect on the shear strength parameters can affect the design and analysis of many geotechnical applications and are explained in the following paragraphs.

\section{Sample size effect on liquefaction triggering analysis}

The instability line (IL) obtained from undrained triaxial compression tests separates the potentially unstable stress states from the stable stress states and therefore constitutes the triggering stress conditions for soil liquefaction (Lade 1992). A soil specimen would liquefy with a rapid reduction of its undrained strength when the undrained stress path crosses IL. According to Fig. 9, IL becomes steeper with decreasing specimen size, which can have significant implications for liquefaction triggering and stability analysis. As liquefaction is triggered when the effective stress path crosses the IL, hence liquefaction triggering resistance increases with decreasing specimen size. Since a larger specimen (70 $\mathrm{mm}$ in Fig. 9) is a closer replicate of field soil, the in-situ 


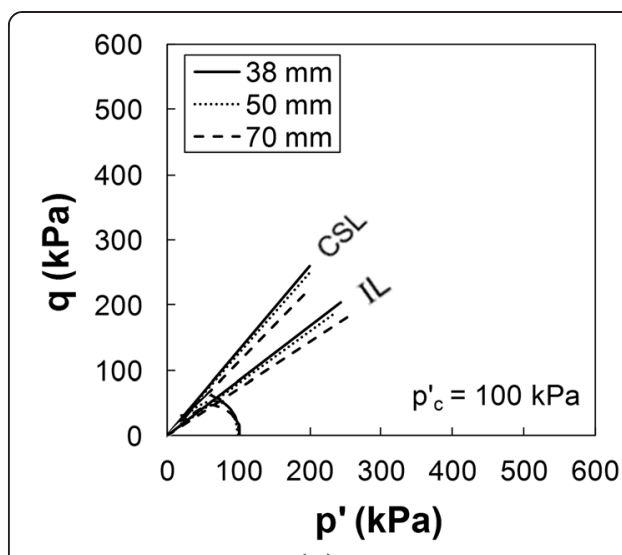

(a)

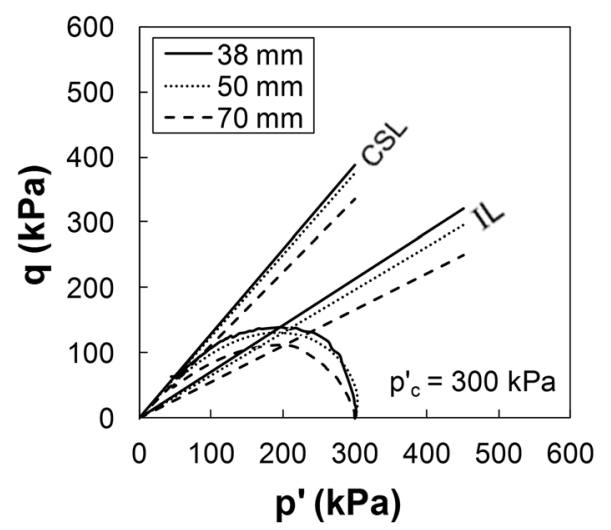

(c)

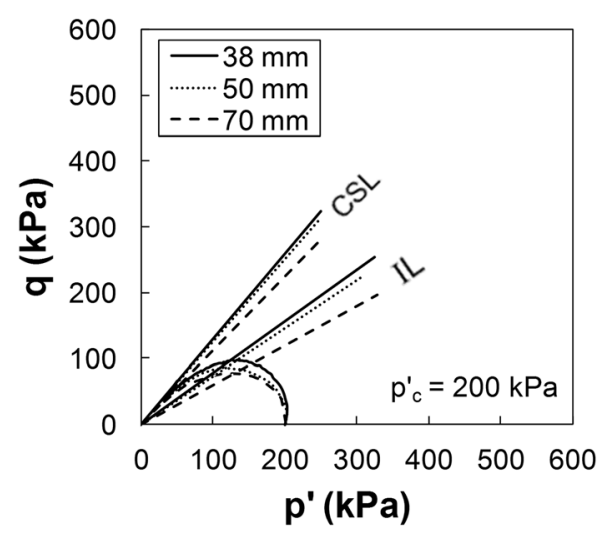

(b)

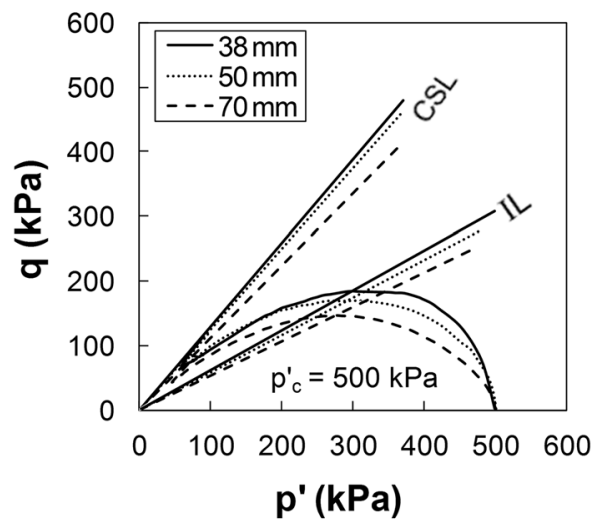

(d)

Fig. 9 Effect of specimen size on undrained effective stress paths of Ottawa sand at (a) $p_{c}^{\prime}=100 \mathrm{kPa}$, (b) $\mathrm{p}_{\mathrm{c}}^{\prime}=200 \mathrm{kPa}$, (c) $\mathrm{p}_{\mathrm{c}}^{\prime}=300 \mathrm{kPa}$, and (d) $\mathrm{p}_{\mathrm{c}}^{\prime}=500 \mathrm{kPa}$

liquefaction potential could be underestimated by triaxial test results on smaller $38 \mathrm{~mm}$ specimens.

\section{Sample size effect on the calibration of a soil constitutive model}

Modeling of soil constitutive behavior as an elastic-plastic material has been the main area of development by many researchers (Lade and Duncan 1975, Jefferies and Shuttle 2002). The differences in sand behavior from different specimen sizes would affect the calibration of soil constitutive models, particularly those based on the critical state theory (Jefferies 1993; Manzari and Dafalias 1997), and their application in advanced numerical analysis. Large errors could arise in the application of soil constitutive models calibrated based on small specimens (e.g., $38 \mathrm{~mm}$ in this study) for predicting the behavior of in-situ soils, or modeling larger soil masses for field applications which could lead to a false assessment of the safety of a soil structure (e.g., slope, foundation, retaining wall) or unsafe designs using numerical analysis with advanced soil constitutive models.

\section{Sample size effect on settlement analysis}

Granular soils are relatively pervious materials that have high permeability and much lower compressibility compared to those of cohesive soils. Accordingly, their 
Table 2 Summary of $\phi^{\prime}$ yield and $\phi^{\prime}{ }_{c s}$ for triaxial tests of this study

\begin{tabular}{|c|c|c|c|c|c|}
\hline $\mathrm{D}(\mathrm{mm})$ & Drainage $^{a}$ & $\begin{array}{l}p_{c}^{\prime} \\
(\mathrm{kPa})\end{array}$ & $\begin{array}{l}D_{\mathrm{rc}} \\
(\%) \\
\end{array}$ & $\begin{array}{l}\phi_{\text {yield }}^{\prime} \\
\text { (degs.) }\end{array}$ & $\begin{array}{l}\phi_{c s}^{\prime} \\
\text { (degs.) }\end{array}$ \\
\hline \multirow[t]{8}{*}{70} & D & 500 & 15 & - & 27.1 \\
\hline & & 300 & 13 & - & 27.8 \\
\hline & & 200 & 11 & - & 28.2 \\
\hline & & 100 & 7 & - & 28.6 \\
\hline & UD & 500 & 14 & 14.2 & 27.3 \\
\hline & & 300 & 12 & 14.7 & 27.9 \\
\hline & & 200 & 9 & 16.4 & 28.4 \\
\hline & & 100 & 7 & 18.2 & 28.7 \\
\hline \multirow[t]{8}{*}{50} & $\mathrm{D}$ & 500 & 18 & - & 30.4 \\
\hline & & 300 & 16 & - & 31.0 \\
\hline & & 200 & 14 & - & 31.2 \\
\hline & & 100 & 10 & - & 31.4 \\
\hline & UD & 500 & 16 & 16.2 & 30.6 \\
\hline & & 300 & 14 & 17.3 & 31.1 \\
\hline & & 200 & 11 & 18.5 & 31.3 \\
\hline & & 100 & 8 & 20.0 & 31.6 \\
\hline \multirow[t]{8}{*}{38} & D & 500 & 18 & - & 31.5 \\
\hline & & 300 & 16 & - & 31.9 \\
\hline & & 200 & 14 & - & 32.1 \\
\hline & & 100 & 10 & - & 32.3 \\
\hline & UD & 500 & 16 & 16.9 & 31.7 \\
\hline & & 300 & 14 & 18.5 & 32.1 \\
\hline & & 200 & 11 & 19.7 & 32.3 \\
\hline & & 100 & 8 & 21.1 & 32.5 \\
\hline
\end{tabular}

${ }^{\mathrm{a}} \mathrm{D}$ and $\mathrm{UD}$ indicate drained and undrained shear, respectively

consolidation settlement is often assumed negligible compared to those of more compressible cohesive soils. However, the compression of sands could be important in the design and analysis of critical structures (e.g., nuclear power plants, advanced laboratories, large dams) to minimize differential settlements. As illustrated in Fig. 3, Ottawa sand exhibits a stiffer isotropic compression behavior in a large specimen $(70 \mathrm{~mm})$. Since no particle crushing was found in any of the conducted triaxial compression tests, we expect that this difference in compressibility resulted from the larger volumetric fraction of the sand particles near the specimen's sides. Accordingly, the specimen size from which soil compressibility is obtained could affect settlement calculations as with smaller specimens, the immediate settlement could be overestimated.

\section{Sample size effect on slope stability analysis}

The accuracy of shear strength parameters is crucial for the analysis of slope failures or the design of new slopes, earth dams, etc. The critical state friction angle $\left(\phi_{\mathrm{cs}}^{\prime}\right)$ is used to analyse the stability of slopes in granular soils, except under very rapid loading conditions (e.g., earthquakes, blasting, vibrations, flow-slides) of saturated granular soils where shear-induced excess pore pressure accumulates and the undrained shear 


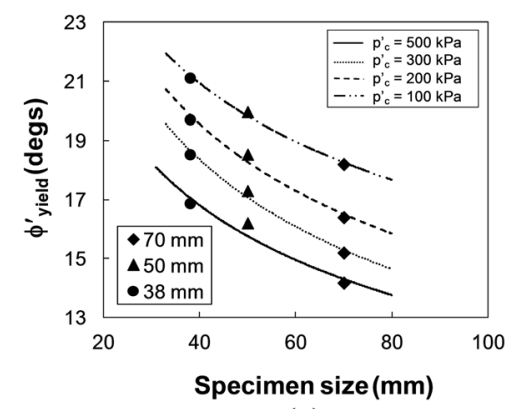

(a)

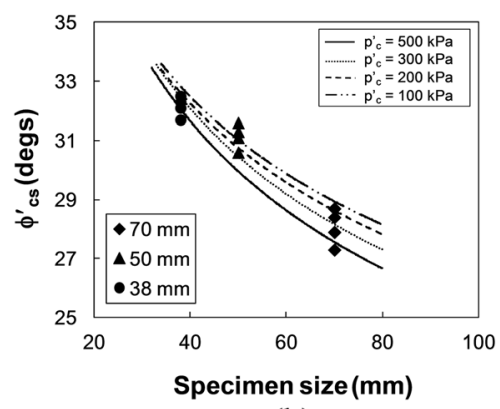

(b)

Fig. 10 Effect of specimen size on (a) $\phi^{\prime}$ yield, and (b) $\phi^{\prime}{ }_{c s}$ from undrained triaxial compression shear tests

strength $\left(\mathrm{s}_{\mathrm{u}}\right)$ would apply. The CSL slope in the stress path diagrams of Fig. 9 reflects $\phi_{\mathrm{cs}}^{\prime}$. Accordingly, the steeper CSL of the smaller specimen would indicate a higher stability and safety of a slope, while being less stable or even at failure based on a more representative $\phi_{\mathrm{cs}}^{\prime}$ from the larger specimen. Testing of larger specimens is recommended and the specimen size effect should be carefully considered in landslides risk assessment.

\section{Sample size effect on bearing capacity of shallow foundations}

Several researchers have investigated the scale effect of different foundation sizes on the bearing capacity factor $\mathrm{N} \gamma$ for shallow foundations (De Beer 1965; Habib 1974; Shiraishi 1990; Zhu et al. 2001; Ueno et al. 2001; Cerato and Lutenegger 2007; Zhu et al. 2001). Zhu et al. (2001) present numerical and physical modeling (with centrifuge tests) studies of scale effect on the bearing capacity of strip and circular footings on dense silica sands. Their findings indicate that the bearing capacity of both strip and circular footings increase with decreasing footing size. Cerato and Lutenegger (2007) further evaluated the trend of decreasing $N_{\gamma}$ with increasing footing width by testing a large range of model-scale square and circular footing sizes, ranging in width from 0.025 to $0.914 \mathrm{~m}$, on two well-graded sands at three relative densities. Their results indicated that $N_{\gamma}$ was dependent on the width of the footing for both square and

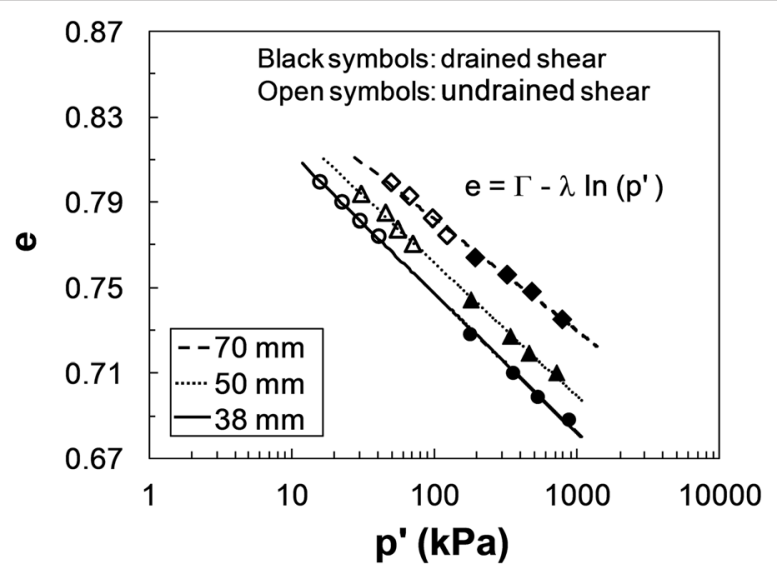

Fig. 11 Effect of specimen size on the CSLs from both drained and undrained triaxial compression shear tests 


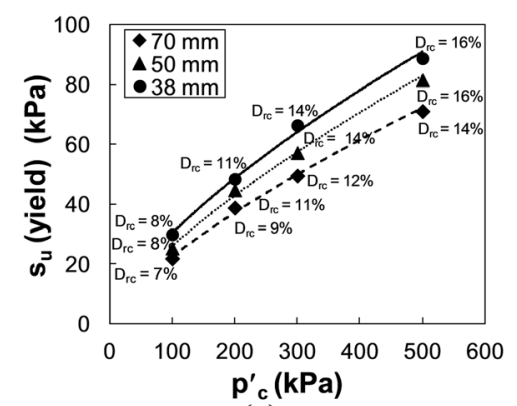

(a)

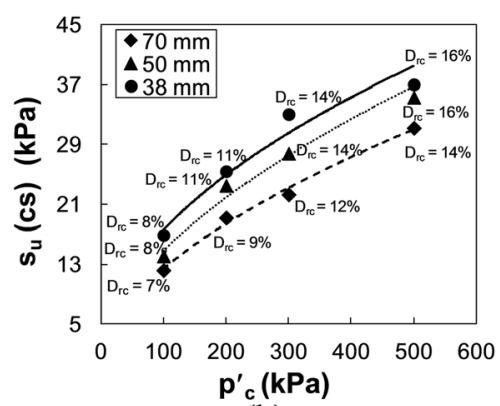

(b)

Fig. 12 Effect of specimen size on (a) $s_{u}$ (yield), and (b) $s_{u}(c s)$ in undrained triaxial compression shear tests

circular footings with the smaller footings exhibiting higher $N_{\gamma}$ values. Bearing capacity factors (Vesic 1975) of $\mathrm{N}_{\gamma}=30.2,26.0$, and 16.7 is obtained from $\phi_{\mathrm{cs}}^{\prime}$ of the $38 \mathrm{~mm}$, $50 \mathrm{~mm}$, and $75 \mathrm{~mm}$ specimen sizes, respectively. Therefore, differences in $\phi_{\mathrm{cs}}^{\prime}$ of different specimen sizes can lead to different bearing capacity factors, with the smaller specimen size producing a higher $\mathrm{N}_{\gamma}$ value. For example, an increase of $4^{\circ}$ in $\phi_{\mathrm{cs}}^{\prime}$ from the $70 \mathrm{~mm}$ to the $38 \mathrm{~mm}$ specimen diameter leads to an $80 \%$ increase in $\mathrm{N}_{\gamma}$. Accordingly, the allowable bearing capacity would be significantly overestimated using strength parameters of small specimens (e.g., $38 \mathrm{~mm}$ ), which could then lead to less safe foundation dimensions and the possibility of unexpected large settlements associated with soil failure. The observed specimen size effect is similar to the particle size effect introduced by Tatsuoka et al. (1991) and Kusakabe (1995). In both cases, larger number of longer shear bands form in a larger triaxial specimen or beneath a larger footing, which reduces the overall amount of the shear resistance mobilized along multiple shear bands.

\section{Sample size effect on lateral earth pressure}

The design of earth retaining walls, abutments, mechanically stabilized earth walls, and reinforced soil slopes is a challenging geotechnical problem (Holtz et al. 2001). The basic design approach for these structures is to design against sliding, overturning, or bearing capacity failure. In all of these phases of design, the lateral active earth pressure coefficient, $k_{a}$, plays a vital role. The measured $\phi_{c s}^{\prime}$ for different sample sizes indicate lower $k_{\mathrm{a}}$ for larger specimens. Accordingly, the $\phi_{\mathrm{cs}}^{\prime}$ differences realized as a result of differences in specimen size could significantly affect the lateral earth pressures and therefore the sliding and overturning analysis and design of retaining structures. Therefore, obtaining the soil strength properties by testing of larger specimens allows for building safer structures. These results further explain the reduced cone penetration resistance of larger cones (Eid 1987), and the smaller effective lateral stresses of large diameter piles (Lehane et al. 2005).

\section{Conclusions}

Scale effects have been observed in many practical engineering problems by several researchers and presented in this study. The triaxial test results on very loose Ottawa sand indicated that sand behavior was affected by the size of the specimen during isotropic compression as well as during drained and undrained shear. The larger 
specimens presented less compressible isotropic compression behavior than the smaller specimens. During shear, the smaller specimens exhibited steeper CSL, reflecting a higher compressibility and mobilized larger friction angles and shear strengths. The smaller volumetric fraction of the more compressible sand zones near the specimen sides and the stiffer regions adjacent to the specimen caps as well as the longer and larger number of shear bands and failure planes in the larger specimens could have produced the observed specimen size effects. The shear strength parameters obtained from testing samples with different sizes could largely affect almost all geotechnical engineering applications in which soil shear strength and friction angle play important roles. The results of using shear strength parameters of three different specimen sizes indicated that: the liquefaction triggering resistance increases with decreasing specimen size, large errors could arise in the calibration and application of constitutive models, uncertainty in stability analyses and safety of slopes and retaining structures, and the bearing capacity factor $\mathrm{N}_{\gamma}$ increases with decreasing specimen size. Accordingly, using the results of smaller specimens could lead to falsely higher liquefaction triggering resistance (and thus underestimated liquefaction potential), unsafe designs with numerical analysis which use advanced soil constitutive models, higher static and seismic factors of safety in slope stability analyses, less safe foundation dimensions, and a falsely higher factors of safety in designing retaining structures. These outcomes highlight the significant influence of specimen size in geotechnical engineering design. Testing larger specimen sizes provides better representation of field shear and deformation behavior, and therefore building safer structures.

Competing interests

The authors declare that they have no competing interests.

\section{Authors' contributions}

Both authors contributed extensively to the work presented in this paper. To carried out all the experimental work in the Geotechnical Research Center of Western University and did the analysis and drafted the manuscript. As supervised the overall work, and edited the manuscript. This research is funded by NSERC Research Grant. All authors read and approved the final manuscript.

Received: 18 December 2014 Accepted: 22 May 2015

Published online: 09 June 2015

References

Alshibli, KA, \& Sture, S. (2000). Shear band formation in plane strain experiments of sand. Journal of Geotechnical and Geoenvironmental. Engineering, 126(6), 495-503.

Andrews, EW, Gioux, G, Onck, P, \& Gibson, JL. (2001). Size effects in ductile cellular solids. Part II: experimental results. International Journal of Mechanical Sciences, 43(3), 701-713.

ASTM Standard D2487. (2011). Standard practice for classification of soils for engineering purposes (Unified Soil Classification System). West Conshohocken, PA: ASTM International. http://www.astm.org.

ASTM Standard D854. (2014). Standard test methods for specific gravity of soil solids by water pycnometer. West Conshohocken, PA: ASTM International. http://www.astm.org.

ASTM Standard D4253. (2006). Standard test methods for maximum index density and unit weight of soils using a vibratory table. West Conshohocken, PA: ASTM International. http://www.astm.org.

ASTM Standard D4254. (2006). Standard test methods for minimum index density and unit weight of soils and calculation of relative density. West Conshohocken, PA: ASTM International. http://www.astm.org.

ASTM Standard D4767. (2011). Standard test method for consolidated undrained triaxial compression test for soils. West Conshohocken, PA: ASTM International. http://www.astm.org.

ASTM Standard D7181. (2011). Standard test method for consolidated drained triaxial compression test for soils. West Conshohocken, PA: ASTM International. http://www.astm.org.

Baldi, G, \& Nova, R. (1984). Membrane penetration effects in triaxial testing. Journal of Geotechnique, 110(3), 403-420

Bastawros, AF, Bart-Smith, H, \& Evans, AG. (2000). Experimental analysis of deformation mechanisms in a closed-cell aluminum alloy foam. Journal of the Mechanics and Physics of Solids, 48(2), 301-322.

Bishop, AW, \& Green, GE. (1965). The influence of end restraint on the compression strength of a cohesionless soil. Journal of Geotechnique, 15(3), 243-266.

Black, DK, \& Lee, LL. (1973). Saturating laboratory samples by back pressures. Journal Soil Mechanical and Foundation Engineering, 99(MSI), 75-93. 
Cerato, AB, \& Lutenegger, AJ. (2007). Scale effects of shallow foundation bearing capacity on granular material. Journal of Geotechnical and Geoenvironmental Engineering, 133(10), 1192-1202.

Chen, C, \& Fleck, NA. (2002). Size effects in the constrained deformation of metallic foams. Journal of the Mechanics and Physics of Solids, 50(5), 955-977.

Colliat-Dangus, J, Desrurs, JL, \& Foray, P. (1988). Triaxial testing of granular soil under elevated cell pressure" Advanced Triaxial Testing of Soil and Rock. In RT Donaghe, RC Chaney, \& ML Silver (Eds.), ASTM STP 977 (pp. 290-310). Philadelphia: American Standard for Testing and Materials.

De Beer, EE. (1965). The scale effect on the phenomenon of progressive rupture in cohesionless soils. Proceedings of the 6th International Conference on Soil Mechanics and Foundation Engineering, 2(6), 13-17.

Desrues, J, Chambon, R, Mokni, M, \& Mazerolle, F. (1996). Void ratio evolution inside shear bands in triaxial sand specimens studied by computed tomography. Journal of Geotechnique, 46(3), 529-546.

Eid, WK. (1987). Scaling effect in cone penetration testing in sand" (PhD Thesis. Virginia Polytechnic Institute and State University).

Finno, RJ, Harris, WW, Mooney, MA, \& Viggiani, G. (1996). Strain localization and undrained steady state of sand. Journal of Geotechnical Engineering, 122(6), 462-473.

Garga, V, \& Zhang, H. (1997). Volume changes in undrained triaxial tests on sands. Canadian Geotechnical Journal, 34(5), 762-773.

Habib, PA. (1974). Scale effect for shallow footings on dense sand. Journal of Geotechnical Engineering, 100(GT1), 95-99.

Hakamada, M, Kuromura, T, Chino, Y, Yamada, Y, Chen, Y, \& Kusuda, H. (2007). Monotonic and cyclic compressive properties of porous aluminum fabricated by spacer method. Materials Science and Engineering: A, 459(1-2), 286-293.

Holtz, RD, Shang, JQ, \& Bergado, DT. (2001). Soil Improvement" (Chapter 15 in Geotechnical and Geoenvironmental. Handbook, pp. 429-462).

Ishihara, K. (1993). Liquefaction and flow failure during earthquakes. Journal of Geotechnique, 43(3), 351-415.

Jang, DJ, \& Frost, JD. (2000). Use of image analysis to study the microstructure of a failed sand specimen. Canadian Geotechnical Journal, 37(5), 1141-1149.

Jefferies, MG. (1993). Nor-Sand: A simple critical state model for sand. Journal of Geotechnique, 43(1), 91-103.

Jefferies, M, \& Shuttle, DA. (2002). Nor-Sand: Features, calibration and use. Journal of Geotechnique, 113(2), 204-237.

Jefferies, MG, Been, K, \& Hachey, JE. (1990). "Influence of scale on the constitutive behaviour of sand (Proceedings of the 43rd Canadian Geotechnical Conference, pp. 263-273). Laval, Quebec: Prediction and Performance in Geotechnique.

Jeon, I, \& Asahina, T. (2005). The effect of structural defects on the compressive behavior of closed-cell Al foam. Acta Materialia, 53(12), 3415-3423.

Kusakabe, O. (1995). Chapter 6: Foundations. In RN Taylor (Ed.), Geotechnical centrifuge technology (pp. 118-167). London: Blackie Academic and Professional.

Ladd, CC. (1978). Preparing test specimen using under-compaction. Geotechnical Testing Journal, 1, 16-23.

Lade, PV. (1992). Static instability and liquefaction of loose fine sandy slopes. Journal of Geotechnical Engineering, $118(1), 51-72$

Lade, PV, \& Duncan, JM. (1975). Elastoplastic stress-strain theory for cohesionless soil. Journal of Geotechnical Engineering 101(10), 1037-1053.

Lee, KL. (1978). End restraint effects on undrained static triaxial strength of sand. Journal of Geotechnical Engineering 104(6), 687-704

Lehane, BM, Gaudin, C, \& Schneider, JA. (2005). Scale effects on tension capacity for rough piles buried in dense sand. Journal of Geotechnical Engineering, 55(10), 709-719.

Manzari, MT, \& Dafalias, YF. (1997). A critical state two surface plasticity model for sands. Journal of Geotechnique, $47(2), 255-272$

Onck, PR, Andrews, EW, \& Gibson, LJ. (2001). Size effects in ductile cellular solids. Part I: modeling. International Journal of Mechanical Sciences, 43(3), 681-699.

Park, C, \& Nutt, SR. (2001). Anisotropy and strain localization in steel foam. Materials Science and Engineering: A, 299(1-2), 68-74

Rowe, PW, \& Barden, L. (1964). Importance of free ends in triaxial testing. Journal of Soil Mechanics and Foundations, 90(1), 1-27.

Russell, AR \& Khalili, N (2004). Cavity expansion in unsaturated sands. In P. Neittaanmaki, T. Rossi, S. Korotov, E. Onate, J. Periaux, and D. Knorzer, (eds.), Proc. of the 4th European Congress on Computational Methods in Applied Sciences and Engineering (ECCOMAS 2004) Jyvaskyla: Unsaturated Soils 2004, Elsevier (147), 2546 - 2557.

Sadrekarimi, A, \& Olson, SM. (2011). Critical state friction angle of sands. Journal of Geotechnique, 61(9), 771-783.

Sarsby, RW, Kalteziotis, N, \& Haddad, EH. (1980). Bedding error in triaxial tests on granular media. Journal of Geotechnique, 30(3), 302-309.

Sasitharan, S. (1994). Collapse behavior of very loose sand. Edmonton, Alberta: University of Alberta

Shiraishi, S. (1990). Variation in bearing capacity factors of dense sand assessed by model loading tests. Journal of Soils Foundations, 30(1), 17-26.

Tatsuoka, F, Okahara, M, Tanaka, T, Tani, K, Morimoto, T, \& Siddiquee, MSA. (1991). Progressive failure and particle size effect in bearing capacity of a footing on sand" in a proceeding: Proc. ASCE Geotech. Engineering Congress, 1991 (pp. 788--802). Boulder: ASCE Geotechnical Special Puplication.

Tekoglu, C, Gibson, L, Pardoen, T, \& Onck, PR. (2011). Size effects in foams: Experiments and modeling. Progress in Materials Science, 56(2), 109-138

Ueno, K, Miura, K, Kasakabe, O, \& Nishimura, M. (2001). Reappraisal of size effect of bearing capacity from plastic solution. Journal of Geotech. \& Geoenvironmental Engineering, 127(3), 275-281.

Vesic, AS. (1975). Bearing capacity of shallow foundations" Foundation Eng. Handbook, 1st ed (pp. 121-147).

Zhu, F, Clark, J, \& Philips, R. (2001). Scale effect on strip and circular footings resting on dense sand. Journal of Geotechnical. \& Geoenvironmental Engineering, 127(7), 613-622. 